\title{
Evaluation on Low-floor Bus Package Layout from the Perspective of Universal Design
}

\author{
Sunwoong Kim ${ }^{1}$, Ji Yeon Kim ${ }^{1}$, Hwan Hwangbo ${ }^{1}$, Bong-Ha Hwang ${ }^{2}$, Yong Joo Moon ${ }^{2}$, Young Gu Ji \\ ${ }^{1}$ Department of Information \& Industrial Engineering, The University of Yonsei, Seoul, 120-749 \\ ${ }^{2}$ Commercial Vehicle Project Team, Hyundai Motor Company, Wanju, 565-904
}

\begin{abstract}
Objective: The aim of this study is to suggest a package layout guideline for low-floor bus by interview with passengers and observations of their behavior. Background: Increasing attention has been introduced the low-floor bus to be more suitable for use by transportation handicapped. Complex issues are involved in providing comfortable services to all people. We are going to suggest package layout guidelines for more comfortable and suitable travel to all people. Method: The two times of survey and video observation sessions were conducted on low-floor buses in Seoul; (1) a finding of potential issues in the first session, (2) a confirming of issues from the last session. Results: The three of major issues were founded in this study; (1) difficulties in supporting body when standing, (2) difficulties in sitting on front wheel pan seat, (3) difficulties in passing through the aisle. Conclusion: There were clear differences between public and transportation handicapped in using some tools which are used for support body such as roof hand rails, side hand rails, and hand rail rings. Some of design problems were founded to improve from the perspective of ergonomics and universal design. Such differences and design guidelines have to be considered in bus design as well as commercial vehicle. Application: The proposed design guidelines can be used to development of low-floor bus and other public transportations.
\end{abstract}

Keywords: Low-floor bus, Universal design, Bus design guideline, Bus interior packaging

\section{Introduction}

세계적인 고령화 추세 중에서도 우리나라의 고령화 추세 는 가장 빠르게 진행되고 있으며, 2026년에는 20\%를 넘어 초고령사회로 진입할 것으로 전망하고 있다(Kang et al., 2007). 고령인구의 비율이 증가하면서 이들의 사회/여가 활동도 함께 증가하고 있다. 이와 함께 복지 수준이 높아지 면서 신체적/감각적/인지적 불편을 겪고 있는 사람들의 사 회 참여도 높아지고 있다. 이러한 사회적 변화를 반영하여 장애인 및 노약자가 일반 시내버스를 이용하는데 편리하도 록 도와주어 사회 참여의 기회를 제공하기 위해 저상버스를 도입하였다.
이러한 사회적 변화를 반영하여 이미 수십 년 전부터 유럽 과 미국 등의 주요 국가에서는 시내버스의 표준형으로 저상 버스를 도입하여 교통약자들의 이동권 보장을 지원하고 있 다. 국내에서도 1997년 처음 개발된 이후, 2002년 이후 그 보급을 점차 늘리고 있으며, 2005년에는 교통약자가 안전하 고 편리하게 이동할 수 있도록 교통수단과 여객시설의 확충 및 개선을 통한 인간중심의 교통체계를 구축함으로써 교통 약자들의 사회 참여와 복지증진에 이바지 한다는 내용을 골 자로 한 '교통약자의이동편의증진법'이 제정되었으며, 2007 년에는 이 법을 바탕으로 '교통약자의이동편의증진계획'을 수립하여 저상버스의 보급을 지속적으로 확대하고 있으며 (MCT, 2007), 2009년 12월 현재 서울시에만 1,215대의 저상버스가 공급되었고, 2013년까지 전국적으로 운행중인

Corresponding Author: Yong Gu Ji. Department of Information \& Industrial Engineering, The University of Yonsei, Seoul, $120-749$.

Mobile: 010-9058-9810, E-mail: yongguji@yonsei.ac.kr

Copyright@2011 by Ergonomics Society of Korea(pISSN:1229-1684 eISSN:2093-8462). All right reserved. 
시내버스의 $50 \%$ 를 저상버스로 도입할 계획이라고 한다 (Seoul city, 2010).

교통약자는 장애인, 고령자, 임산부, 영유아를 동반한 자, 어린이 등 생활을 영위함에 있어 이동에 불편을 느끼는 자 를 말하며(NARK, 2005), 이들 교통약자와 일반인들을 모 두 만족시키기 위해서는 'Design for all', 즉 모든 사람을 위한 디자인을 뜻하는 유니버설 디자인(Universal Design) 측면에서의 설계에 대한 고려가 반드시 필요하다. 유니버설 디자인의 주창자인 Ronald L. Mace는 장애의 유무나 연령 등에 관계없이 모든 사람들이 제품, 건축, 환경, 서비스 등을 보다 편리하고 안전하게 이용할 수 있도록 설계하는 디자인 이라고 정의하였고(Wikipedia), Equitable Use, Flexibility in Use, Simple and Intuitive Use, Perceptible Information, Tolerance for Error, Size and Space for Approach and Use 등 7 가지 원칙에 준해 제품을 설계할 것을 제안하였다.

Table 1. The principles of Universal Design [Source: Story M.F, 1998]

\begin{tabular}{c|l}
\hline Principle & \multicolumn{1}{c}{ Description } \\
\hline $\begin{array}{c}\text { Principle 1: } \\
\text { Equitable Use }\end{array}$ & $\begin{array}{l}\text { The design is useful and marketable to } \\
\text { people with diverse abilities }\end{array}$ \\
\hline $\begin{array}{c}\text { Principle 2: } \\
\text { Flexibility in Use }\end{array}$ & $\begin{array}{l}\text { The design accommodates a wide range } \\
\text { of individual preferences and abilities }\end{array}$ \\
\hline $\begin{array}{c}\text { Principle 3: } \\
\text { Simple and } \\
\text { Intuitive Use }\end{array}$ & $\begin{array}{l}\text { Use of the design is easy to understand, } \\
\text { regardless of the user's experience, } \\
\text { knowledge, language skills, or current } \\
\text { concentration level }\end{array}$ \\
\hline $\begin{array}{c}\text { Principle 4: } \\
\text { Perceptible } \\
\text { Information }\end{array}$ & $\begin{array}{l}\text { The design communicates necessary } \\
\text { information effectively to the user, } \\
\text { regardless of ambient conditions or the } \\
\text { user's sensory abilities }\end{array}$ \\
\hline $\begin{array}{c}\text { Principle 5: } \\
\text { Tolerance for } \\
\text { Error }\end{array}$ & $\begin{array}{l}\text { The design minimizes hazards and the } \\
\text { adverse consequences of accidental or } \\
\text { unintended actions }\end{array}$ \\
\hline $\begin{array}{c}\text { Principle 6: } \\
\text { Low Physical } \\
\text { Effort }\end{array}$ & $\begin{array}{l}\text { The design can be used efficiently and } \\
\text { comfortably and with a minimum of } \\
\text { fatigue }\end{array}$ \\
\hline $\begin{array}{c}\text { Principle 7: } \\
\text { Approach and Use }\end{array}$ & $\begin{array}{l}\text { Appropriates size and space is provided } \\
\text { for approach, reach, manipulation, and } \\
\text { use regardless of the user's body size, } \\
\text { posture, or mobility }\end{array}$ \\
\hline
\end{tabular}

버스나 지하철과 같은 대중교통 차량을 이용하는 사람들 은 어린 아이에서부터 노인까지 연령에 제한이 없으며, 건강 한 사람에서부터 신체적/감각적/인지적 능력이 상대적으로 부족한 어린아이나 노인, 그리고 신체적/지적/정신적 장애가 있는 장애우까지 능력이나 조건에 제한이 없다. 즉, 그 어느
제품이나 서비스 보다 유니버설 디자인에 신경을 써야 할 대 상이 바로 버스와 같은 대중교통 차량인 것이다.

서울시에서 조사한 대중교통 이용자 실태 분석 결과에 따 르면, '공영차고지 설치 및 운영조례'에 따라 구분한 대권역별 - 서울 5 개 권역, 경기 11 개 권역 - 수송 분담률 중 권역 내 통행은 버스가 $38.9 \%$ 로 가장 많이 분담하고 있는 것으 로 나타났으며, 권역 간 통행은 지하철이 $60.1 \%$ 로 가장 많 이 분담하는 것으로 나타났다. 교통수단별 총 수송 분담율은 지하철 (36.2\%)이 가장 높았으며 그 다음이 버스 $(27.5 \%)$, 승용차(25.6\%) 순이었다(Seoul, 2007).

2006년 고령자들이 이동을 위한 통행수단으로 버스 $(28.5 \%)$ 를 가장 많이 이용하는 것으로 나타났으며, 도보/자 전거(27.6\%), 승용차(19.5\%), 지하철(19.2\%)가 뒤를 이 었다. 버스 이용율이 $28.5 \%$ 로 가장 높게 나타났지만, 1996 년 $45 \%$ 에서 약 $16.5 \%$ 포인트 가량 감소한 수치이다 $(\mathrm{Ma}$ $\&$ Yoon, 2009). 이에 대한 원인으로 은퇴로 인한 경제적 부담과 통행 목적의 변동을 주된 원인으로 꼽았지만, 버스 를 제외한 타 교통수단 모두가 최소 $2 \%$ 포인트에서 약 $8 \%$ 포인트까지 증가한 것을 감안한다면, 그 외에도 다른 요인들 이 있을 것으로 생각된다.

Kim et al.(2004)은 교통약자의 이동권 확보를 위한 보 행 및 여객시설 등의 편의시설 설치 수준을 평가 분석하여 교통약자이동편의 증진법의 방향 및 설치 기준을 제시하였 다(Kim et al., 2008).

Kim et al. (2008)이 수행한 교통약자의 교통수단에 대한 만족도 조사에서 지하철에 대한 만족도(100점 만점)가 54.3 점인 반면 버스는 39.0점으로 상당한 차이가 있었으며, 일반 인 또한 지하철(61.6점)에 비해 버스(51.6점)에 대한 만족 도가 상대적으로 낮게 분포해 있었다.

Seo et al. (2006)은 고령자의 통행특성과 통행행태 분석 을 통해 일반인들은 통행시간과 통행비용 모두에 민감한 반 면 고령자는 통행비용에는 민감하지만 통행시간에는 민감하 지 않다는 것을 주장하였다. 이에 대한 배경으로 고령자들은 일반적으로 시간적 여유가 많지만 경제적인 여유가 부족한 것을 들었다. 또한 이를 통해 이들 고령자들이 선호하는 대 중교통수단에 대한 지속적인 연구 필요성을 제기하였다.

대중교통 시설과 교통약자 관련 선행연구들은 대부분 교 통약자의 대중교통 시스템의 사용 실태 분석에 국한되어 있 고, 그나마도 대부분 정류장, 지하철역, 환승 센터 등과 같은 시설물에 중점을 두고 있다.

승용차와 지하철의 경우 차량 내 각종 첨단 기술과 편의시 설이 적용되고 운전자 내지는 탑승객의 안락감/편의성 향상 을 위한 연구가 많이 이루어 지고 있지만 버스를 대상으로 이러한 연구들은 전혀 수행되어지지 않았다. 교통약자를 배 려한 저상버스의 보급이 급격이 증가하고 있는 현 시점에 
탑승객의 안전성, 편의성, 및 안락함을 저해하는 요인들을 찾아내고 이들에 대한 인간공학적 유니버설 디자인 측면의 개선에 대한 연구가 필요하다.

이에 본 연구에서는 설문조사/인터뷰와 비디오 관찰을 통 해 교통약자와 일반인의 저상버스 이용과 관련된 실내 레이 아웃 및 구조물 관점에서의 사용 맥락에 기반한 문제점을 도출을 하고, 앞서 소개한 Ronald L. Mace의 유니버설 디 자인 7 원칙의 관점에서 이에 대한 개선안을 도출함으로써 교통약자와 일반인에게 동일한 수준의 편의와 만족을 제공 할 수 있는 저상버스 설계를 위한 디자인 방안을 제시하고 자 한다.

\section{Method}

일본의 유니버설 디자인 솔루션업체인 트라이포드 디자인 (Tripod Design)은 유니버설 디자인을 위해 잠재된 문제 점을 최소화하고 사용자를 만족시키기 위한 제품 개발을 위 해서는 체계적 모니터링이 필요하다고 하였다(Kim et al., 2006).

본 연구에서는 실제 저상버스 탑승객들을 대상으로 설문 조사/인터뷰를 실시하고 저상버스 내 승객의 행동을 모니터 링하기 위해 비디오 관찰을 수행하였다. 이들 설문조사/인터 뷰 및 비디오 관찰 결과로부터 저상버스 이용 시 승객들의 주요 불편/불만 사항을 도출하고, 유니버설 디자인 관점에서 이들 주요 불편/불만사항에 대한 근본 요인을 찾아내고 이들 에 대한 개선안을 제시하고자 하였다.

\subsection{Survey and in-depth interview}

전/중문, 좌석의 종류, 핸드레일, 손잡이, 휠체어 고정장치 등 저상버스의 실내 구조물을 각각의 기능과 역할에 따라 구 분하여 분석을 실시하였다. 이들 구조물들은 다시 위치, 크 기, 길이, 그립감 등의 디자인 요소 수준으로 평가 대상을 세분화 하고, 만족도, 편의성, 시인성, 승강성, 통행성, 성능 등의 디자인 요소에 대한 평가 요소를 결정하였다.

세분화된 디자인 요소와 평가 요소의 매칭을 통해 주요 설 문 항목을 도출하였고, 이를 기반으로 하여 설문지를 개발하 였다.

1 차 설문 결과와 비디오 관찰 결과를 종합하여 저상버스 내 구조물 이용편의 및 만족 전반에 관한 예비 문제점을 도 출하였다. 이후 심층인터뷰 형식의 2차 설문조사를 실시하여 도출된 예비 문제점들에 대한 구체화 및 검증을 실시하였다.

1 차 설문조사와 2 차 심층인터뷰는 각각 약 3 주간에 걸쳐
진행되었으며, 1 차 설문조사에는 탑승대기 승객, 버스 탑승 승객을 대상으로 하였으며, 비디오 관찰 결과와의 연관/비교 분석을 위해 비디오카메라를 설치한 차량에서도 설문조사를 실시하였다. 2 차 심층인터뷰에서는 저상버스 탑승객이 느끼 는 불편/불만 사항을 현장에서 생생하게 듣기 위해 저상버스 내에서 탑승객을 대상으로 $1: 1$ 심층인터뷰를 실시하였다.

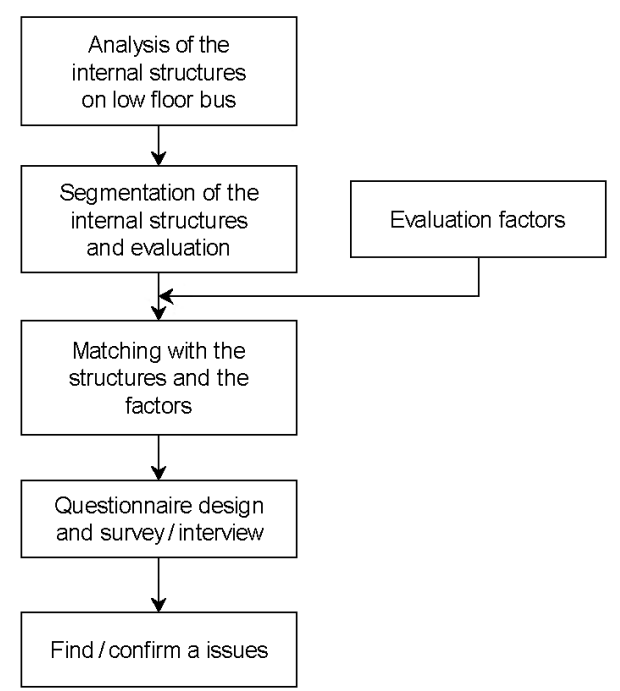

Figure 1. Survey/interview process

1 차 설문조사와 2 차 심층인터뷰에 대한 개략적인 데모그 래픽은 Table 2 와 같다.

Table 2. Survey demographics

\begin{tabular}{c|c|c}
\hline & $1^{\text {st }}$ Survey & $2^{\text {nd }}$ Interview \\
\hline A number of respondents & 208 & 58 \\
\hline Gender ratio & $\mathrm{M}: \mathrm{F}=4: 6$ & $\mathrm{M}: \mathrm{F}=4: 6$ \\
\hline Average age & 34.5 & 33.3 \\
\hline Average height $(\mathrm{cm})$ & 166.1 & 166.1 \\
\hline
\end{tabular}

\subsection{Video observation}

지금까지 진행되어온 대부분의 소비자 조사는 응답자 자 신이 스스로 질문에 응답을 하는 '자기보고' 방식으로 이루어 져 왔다. 하지만 점차 이러한 소비자 조사의 결과들이 소비 자를 제대로 이해시킬 수 있는 지에 대한 의문이 증가하고 있는데, 이는 소비자의 내면이 너무 복잡하고 스스로 자기 행동의 이유를 명확하게 설명하지 못하고 있기 때문이다.

이러한 현상에 대해 Zerald Zaltman 하버드대 교수는 'How Customers Think'라는 저서를 통해 소비자들의 사 
고 중 $95 \%$ 가 무의식적으로 발생한다고 주장하였고, 정신분 석학적 심리학의 대표 학자인 프로이트도 인간의 의식은 빙 산의 일각에 불과하며 무의식에 의해 사고와 행동이 일어나 게 된다고 하였다(Zaltman, 2003). 이는 점점 감성의 시대 로 접어들면서 지금까지의 전통적인 조사 방법인 설문조사 방법만으로는 소비자의 욕구를 파악하는 데에는 한계가 있 다는 것이다.

이에 본 연구에서는 비디오 관찰법을 통하여 저상버스 내 승객의 행동을 정성적으로 관찰하고 승객의 유형 및 사용 맥 락(context)에 따라 승객의 행동을 패턴화하여 교통약자와 일반인의 실내 구조물 이용에 대한 특성 및 불편 요인을 객 관적으로 도출하고자 하였다.

비디오 관찰에서도 설문조사와 마찬가지로 총 2 차에 걸쳐 진행되었다. 1 차 비디오 관찰은 2 주, 2 차는 약 1 주의 기간 동안 각각 2 대의 서울시내를 운행하는 간선 저상버스를 대 상으로 진행하였다. $1 / 2$ 차 총 4 대의 관찰 대상 저상버스는 서울 도심, 대학가, 주택가를 모두 경유하는 노선을 운행하 는 버스를 선정하였다. 승객이 차량에 탑승, 체류, 및 하차하 는 전 과정을 가능한 상세히 분석하기 위해 각 차량별 4 대 의 카메라를 할당하였고, 호손 효과를 방지하기 위해 승객의 눈에 잘 띄지 않는 천장 구역에 설치하였다.

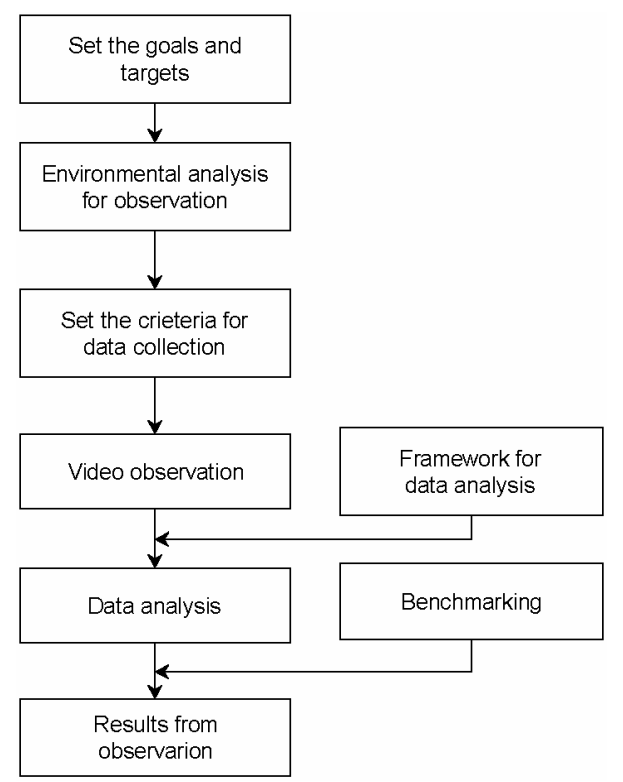

Figure 2. Video observation process

비디오 관찰을 위한 목표를 수립하고 관찰 대상을 선정한 후 비디오 관찰 환경 분석을 실시하였다. 이를 통해 카메라 설치 환경을 조성하고 관찰 기간 및 방식을 결정하였다. 이 어 데이터 수집 기준과 데이터 기록 양식을 개발하고 차량
에 비디오를 장착 후 관찰을 실시하였다.

수집된 데이터는 사건 단위로 기록한 후 다시 사용 맥릭 (Context of use)에 따라 분석하였다. 분석에 사용된 사용 맥락은 Maguire의 연구(2001)에 제시된 components of context of use analysis를 차용하여 전문가 팀(HCI 전문가, 저상버스 관련 전문가)이 FGI를 통해 도출하였다(Kim et al., 2011).

\section{Results}

승객들이 저상버스 내 구조물들에 대한 만족도, 편의성 등 의 설문조사 결과들을 비디오 관찰 결과와 비교 분석을 실시 하였으며, 추가로 승객들의 무의식적인 행동으로부터 불편 요인을 찾아내고자 하였다.

\subsection{Results from the survey and in-depth interview}

\subsubsection{Results from the Survey}

1차 설문 결과 Figure 3과 같이 Wheel pan 부 seat, seat 손잡이 등에 대한 만족도가 가장 낮게 나타났으며, 스텐션 폴, LED 전광판, 카드 리더기, 콜 부저 등의 만족도는 상대 적으로 높게 나타났다. 나머지 항목들의 경우 보통인 4 점 이 상의 점수를 획득하기는 하였지만, 승객들이 만족을 느끼기 에는 많이 부족해 보인다.

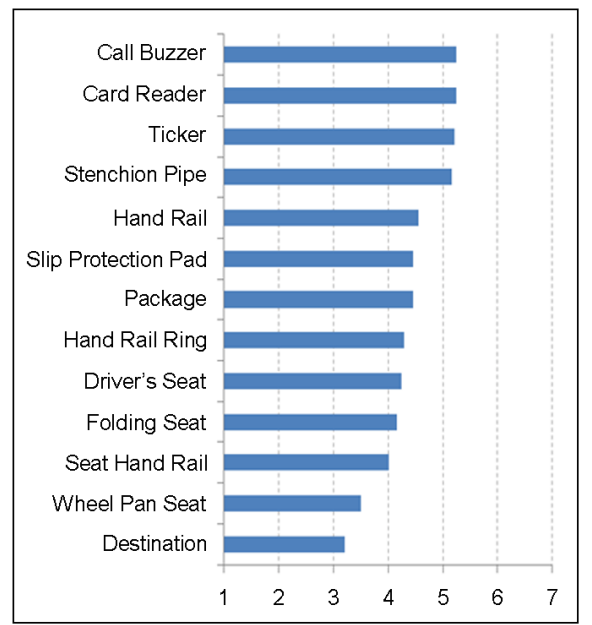

Figure 3. Satisfaction on low-floor bus interior

저상버스의 전반에 대한 만족도와 각 구조물간 상관관계 분석 결과 좌석 손잡이, 창문, 일반 좌석 등에 대한 만족도가 
높을수록 저상버스 전반에 대한 만족도가 높은 것으로 나타 났다(Table 3).

Table 3. Summary of high correlation and significant results

\begin{tabular}{c|c|c}
\hline \multirow{2}{*}{$\begin{array}{c}\text { Seat } \\
\text { handle }\end{array}$} & Correlation coefficient & 0.411 \\
\cline { 2 - 3 } & $p$-value & $0.030^{*}$ \\
\hline \multirow{2}{*}{$\begin{array}{c}\text { Side } \\
\text { window }\end{array}$} & Correlation coefficient & 0.454 \\
\cline { 2 - 3 } Passenger & $p$-value & $0.015^{*}$ \\
\cline { 2 - 3 } seat & Correlation coefficient & 0.342 \\
\hline \multicolumn{2}{c}{$p$-value } & 0.075 \\
\hline
\end{tabular}

\subsubsection{Results from in-depth interview}

심층인터뷰 시 조사한 각 구조물에 대한 만족도와 중요도 조사 결과를 Figure 4와 같이 도식화 하였다

실내 구조물 중 스텐션 폴은 중요도와 만족도 모두 높은 항목으로 승객의 편의를 위한 실내 구조물 설계에서 중요한 요인인 것으로 확인되었다.

휠팬부 시트와 노선도의 경우 중간 정도의 중요도 순위를 보였으나 이에 대한 만족도는 매우 낮은 것으로 조사되었다. 일반 좌석, 핸드레일 손잡이, 좌석 손잡이 등은 중요도 우선 순위가 매우 높았으나 그에 대한 만족도는 다소 떨어지는 것 으로 나타났으며, 창문, 핸드레일, 미끄럼 방지패드, 접이식 시트(휠체어 고정을 위해 좌-우 양쪽에 총 4개의 접이식 시트를 배치하고 있음)의 경우 만족도와 중요도 우선 순위 모두 중간으로 조사되었다.

스텐션 폴, 좌석 손잡이, 핸드레일 손잡이, 핸드레일 등은 차량 내에서 이동을 하거나 체류 시 신체 지지를 목적으로 하는 구조물들로 이들에 대한 우선 순위가 높은 반면 만족도 는 다소 낮았다.

인터뷰에서 대부분의 교통약자들은 착석에 대한 욕구가
강한 것으로 나타났고, 이는 일반 좌석의 중요도 우선 순위 가 높게 나타나는 요인으로 작용한 듯 하다. 하지만, 전방 휠 팬부 시트는 강한 착석에 대한 욕구에도 불구하고 차량의 구 조적 문제로 앉고 일어서기가 쉽지 않아 중요도 우선 순위가 중간으로 나타났다.

\subsection{Results from video observation}

승객들의 비디오 관찰 결과 승객들의 행동 패턴을 크게 승차, 차내 체류, 하차의 3 가지로 그룹핑을 할 수 있었다. 승 차와 관련된 구조물로는 도어 손잡이, 스텐션 폴, 카드 리더 기 등이 있었고, 차량 내 체류와 관련된 구조물로는 스텐션 폴, 핸드레일, 일반/접이식 좌석 등 차량 내의 대부분의 구 조물들과 연관이 있었다. 마지막 하차와 관련된 구조물로는 하차벨, 카드 리더기, 중문 핸드레일 등의 구조물이 관련이 있는 것으로 나타났다.

비디오 관찰에 대한 기초 분석 결과 약 1,000 여건의 사건 이 기록되었으며 남/여 성별 이벤트 기록 건수는 거의 유사 하게 나타났다. 교통약자와 관련된 사건은 약 260 여건이 있 었으며, 이 중 장애인과 관련된 것은 총 4 건에 불과하였으며 이들 모두 비 휠체어 탑승 장애인으로 저상버스 도입의 본래 취지와 달리 실제로 휠체어 장애인의 탑승은 관찰되지 않았 다. 관찰된 교통약자의 경우도 대부분 고령층인 것으로 확인 되었다.

일반인 남성들의 경우 저상버스 이용에 비교적 큰 불편 없 이 이용이 가능한 것으로 나타났다. 이에 반해 일반인 여성 은 차량 내에서 이동에 대한 문제는 쉽게 발견되지 않았으 나, 남성에 비해 상대적으로 작은 키로 인해 입석 시 차량 내에서 가장 쉽고 안정적으로 신체를 지지할 수 있는 핸드레 일을 사용하지 못 하는 경우를 쉽게 관찰할 수 있었으며, 비 교적 불안전한 핸드레일 손잡이나 상대적으로 개수가 적은 스텐션 폴 혹은 위치에 제약을 받는 좌석 손잡이 등을 주요 지지 구조물로 사용하는 것으로 나타났다. 이는 키가 작은

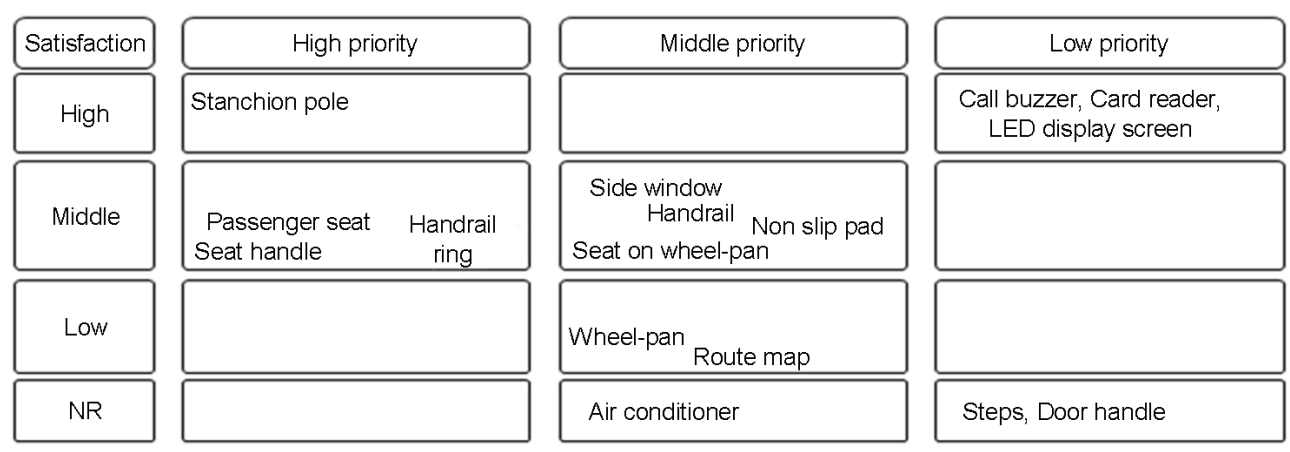

Figure 4. Video observation process 
일반인 남성에게서도 쉽게 관찰되었다.

교통약자의 남성의 경우 일반인 남성과 비슷한 행태를 보 였는데, 이는 신체적, 물리적 제약이 교통약자 여성에 비해 적기 때문인 것으로 판단된다. 반면에 교통약자 여성의 경우 일반인에 비해 상대적으로 작은 신장과 신체적/감각적 노화 로 저상버스 내 활동에 제약이 있었으며, 특히 입석 시 신체 를 적절히 지지하기 어려워 출발, 회전, 정차 등의 상황에서 큰 불편을 겪고 있는 것으로 나타났다.

구조물에 대한 사건 분석 결과를 보면, 전방 휠팬부 시트 에 착석하는 것이 쉽지 않은 것으로 확인되었다.

Figure 5는 비디오 촬영에 의해 관찰된 사례로 휠팬부 시 트에 착석을 수 차례 시도한 끝에 힘겹게 앉는 장면이다.

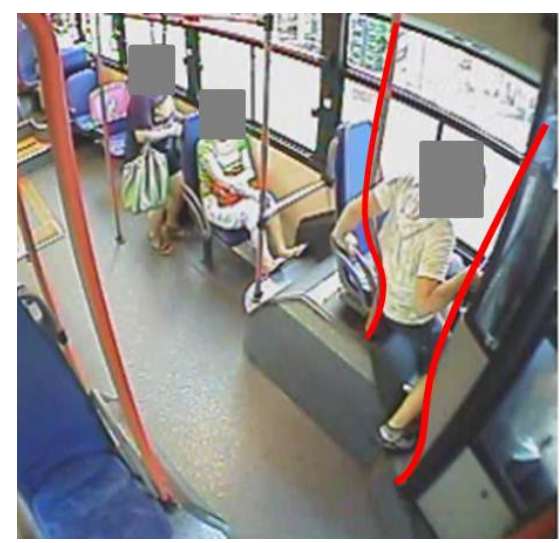

Figure 5. Passenger feels difficulty in sitting on wheel pan seat

중문 전방의 경우 차량 내부의 혼잡도가 조금만 증가하면 핸드레일이나 핸드레일 손잡이를 잡고 있는 승객들이 차량 내부에서 이동을 하려는 승객들의 통행을 방해하는 경우도 자주 관찰되었으며, 중문 후방의 경우는 Figure 6과 같이 차 량 내부 혼잡도와 무관하게 스텐션 폴을 피해 몸을 좌/우로 피하면서 이동하는 것을 관찰할 수 있었다.

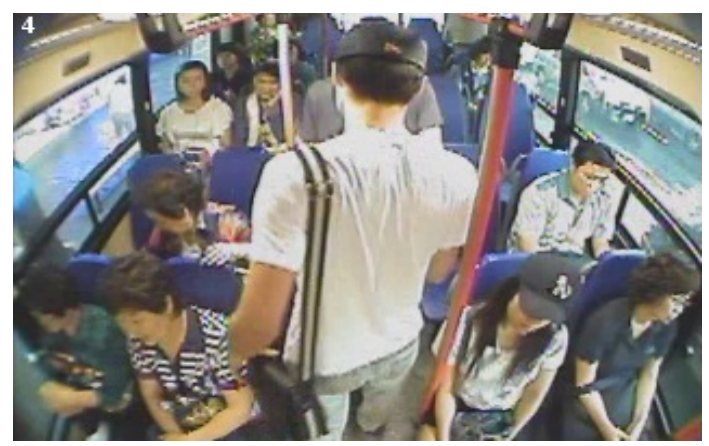

Figure 6. Passenger feels difficulty in go through an aisle

\section{Guideline Suggestion from Findings}

앞에서 살펴본 1 차 설문조사 결과, 인터뷰 결과 및 비디오 관찰 결과를 종합적으로 고려하여 주요 문제점을 도출하고, 그들과 관련된 저상버스 실내 구조물을 정리하였다.

(1) 기립 시 신체 지지의 어려움(Difficulties in supporting body when standing): 핸드레일 손잡이, 좌석 손잡이, 스텐션 폴, 핸드레일 등

(2) 전방 휠팬부 시트 착석의 어려움(Difficulties in sitting on a front wheel pan seat): 휠팬부 시트, 스텐션 폴, 운전석 격벽 등

(3) 차량 내 통행 불편(Difficulties in passing through the aisle): 스텐션 폴, 핸드레일 등

위의 세 가지 주요 문제들에 대한 원인 분석을 실시하고, 이를 근거로 한 다음과 같은 간단한 설계 제안을 하고자 한다.

\subsection{Three main difficulties}

저상버스 내 비디오 관찰 결과를 각각의 구조물에 대해 사건 발생 횟수와 문제의 심각도를 정의하고, 설문을 통해 얻어진 만족도점수와 우선 순위를 고려하여 주요 문제가 되 는 구조물을 선별하고 이를 사용 맥락에 기반한 다음과 같은 3 가지의 주요 문제점을 도출하였다.

\subsubsection{Difficulties in supporting body when standing}

입석 시 신체를 지지하는 주요 대상물로 핸드레일 손잡이, 좌석 손잡이, 스텐션 폴, 핸드레일 등이 있다. 승객들이 가장 선호하는 구조물인 스텐션 폴은 개수가 부족하고, 특별한 기 준이 없이 지그재그로 설치되어 있어 명확한 기준에 의한 설 계가 반드시 요구되는 구조물이다. 핸드레일 손잡이의 경우 가장 많이 적용되어 있고, 또 가장 많이 사용하는 지지 구조 물이지만 움직임이 심해 핸드레일 손잡이 단독 사용으로는 적절한 지지가 어려운 상황이다. 이는 비디오 관찰을 통해서 혼잡도가 아주 높은 상황을 제외하면 거의 모든 승객들이 중복 지지를 하고 있다는 것을 통해 확인할 수 있었다. 심지 어 일반인 남성들의 경우 핸드레일 손잡이에 의해 승객 본인 의 머리나 어깨 등에 부딫혀 이를 피하기 위해 손목에 감은 뒤 핸드레일을 잡는 모습도 자주 발견되었다. 휠체어 고정석 에 장착된 접이식 시트 4 개를 제외한 모든 시트에 좌석 손 잡이가 달려있지만 크기가 작아 좌석 승객이 사용할 경우 입석 승객이 사용하기 어렵고, 창가에 적용되어 있는 사이드 
핸드레일의 경우 위치가 부적절하여 일반인 중 큰 체형을 제 외하면 사용이 쉽지 않다.

비디오 관찰 결과를 통한 저상버스 실내 구조물에 따른 지 지 빈도를 보면 승객의 성별에 따른 차이와 신체적 특성에 무관하게 모든 승객이 이용할 수 있는 스텐션 폴의 지지 빈 도가 $76.7 \%$ 로 가장 많았으며 핸드레일 손잡이가 $17 \%$, 상 대적으로 높은 곳에 위치해 특정한 계층(키가 일정 수준 이 상인 승객)만이 사용할 수 있었던 핸드레일은 $6.3 \%$ 로 매우 낮은 것으로 나타났다. $17 \%$ 의 지지 빈도를 보인 핸드레일 손잡이의 경우 단독 지지 빈도는 매우 낮았고 대부분 다른 구조물과 중복 지지하는 경향을 보였다.

지지 구조물로써 가장 빈번하게 사용되는 스텐션 폴의 경 우 다수의 입석 승객이 사용하기에 다소 부족 $(32.1 \%$ 가 부 족하다고 응답 함)한 것으로 조사되었다. 특히 60 대 이상 고령층은 스텐션 폴의 개수가 적당하다고 하였으며, 30대와 40 대는 부족하다고 응답하였다 $(p<0.05)$. 고령층의 경우 젊 은 연령층의 승객으로부터 좌석을 양보 받는 경우가 많고, 기립 시에도 스텐션 폴 부근을 찾아서 지지하기 때문에 큰 불편함을 느끼지 못 하는 것으로 판단된다. 반면에 좌석을 주로 양보하는 20 40대 중, 20대는 상대적으로 키가 커서 높은 곳에 위치한 핸드레일을 잡고 지지하는데 어려움이 없 기 때문에 역시 스텐션 폴의 부족함을 인지하지 못 했을 가 능성이 크지만 30 대와 40 대는 20 대에 비해 백분위 수에 따 라 약 3 6cm 가량 작아(Size Korea, 2003) 핸드레일을 잡 고 지지하는데 불편함이 따른다. 성별로 보면, 남성보다 여 성이 이용 편의에 문제가 많은 것으로 조사되었다 $(p<0.05)$.

저상버스의 창가에 부착되어 있는 사이드 핸드레일도 거 리가 너무 멀어(응답자의 60\%가 멀다고 응답 함) 일부 승 객의 경우 사용 자체가 불가능 했으며, 일부 키가 큰 승객을 제외하면 사이드 핸드레일 사용을 위해 착석 승객에 최대한 가까이 다가서야 하는 불편함과 민망함을 감수해야 했다.

\subsubsection{Difficulties in passing through the aisle}

저상버스 내 승객들의 행동 패턴에서 승차 후 빈 곳을 찾 아 이동 후 앉으려는 행위가 가장 빈번하게 관찰되었다. 차 량 내 혼잡도가 높지 않다면 1인석 공간에서는 큰 문제없이 이동이 가능하지만, 중문 후방 공간에서는 통로쪽으로 스텐 션 폴을 피해 몸을 좌/우로 비틀면서 이동하는 것을 쉽게 관찰할 수 있었다. 통행을 위해 충분하지 않은 공간에 스텐 션 폴이 돌출되어 있어서 이를 피하기 위함이었다.

차량 내 혼잡도가 조금만 높아지면 핸드레일이나 핸드레 일 손잡이를 잡고 서 있는 승객들이 등을 마주하고 위치하 게 된다. 이 때 등을 마주한 승객들이 통로를 막아 앞/뒤로 의 이동을 원활하지 않게 하는 상황이 자주 관찰되었다. 심 지어 입석 승객에 의해 이동을 하지 못하고 한 참을 망설인
끝에 이들 입석 승객 중 한 명의 앞쪽으로 고개를 숙이고 지 나가는 경우도 가끔 목격되었다. 통로쪽으로 너무 치우친 핸 드레일로 인해 입석 승객이 핸드레일이나 핸드레일에 연결 된 핸드레일 손잡이를 편하게 잡기 위한 충분한 공간이 확 보되지 않음으로써 발생되는 문제인 것이다. 입석 승객이 좌 석 승객과 대면하고 있는 지하철의 경우와 비교해서도 너무 멀리 떨어지도록 설계가 되어 있었다.

일부 저상버스의 경우 중문에 카드 리더기가 1 개만 설치 되어 있어 하차 대기중인 승객이 카드 리더기쪽으로 집중되 는 경향이 있었으며, 키가 큰 승객에 대한 배려로 중문부 핸 드레일을 높게 설치한 경우도 있었으나 이는 지나치게 높아 하차 대기 중 적절한 지지를 하지 못하게 되고 이로 인해 중 문 근처의 스텐션 폴 주변으로 승객이 집중되어 통행에 큰 지장을 준다. 실제 비디오 관찰에서도 중문 핸드레일부는 하 차 대기 승객이 없었으나 중문 근처의 스텐션 폴 부근에 하 차 대기 승객이 밀집되어 있어 중문 후방의 빈 좌석으로 이 동하려던 승객이 한참을 망설이다 겨우 용기를 내어 이동하 는 경우도 심심치 않게 관찰되었다.

일부 저상버스의 경우 중문 후방이 step 구조로 되어 있 었고 이는 곧 혼잡도가 어느 정도 이상이 되면 floor를 눈으 로 확인하기가 쉽지 않아 통행에 불편을 주는 요인이었다. 실제 일부 승객들의 경우 중문 이후 step 구조에서 내려오 다 발을 잘 못 디뎌 넘어질 뻔한 경우도 가끔 관찰되었다.

\subsubsection{Difficulties in sitting on a front wheel pan seat}

앞서 살펴본 비디오 관찰 결과와 설문 결과에서 만족도가 유난히 낮게 나타나고 많은 사건이 관찰된 부분이 바로 이곳 전방 휠팬부 좌석이다. 특히, 운전석 뒷 편의 휠팬부 좌석에 대한 불만 사항이 높게 나타났다.

휠팬부 좌석의 높이에 대해 $80 \%$ 이상이 높거나 매우 높 다고 응답하였으나, 높이에 대한 만족도는 4점(7점 만점)으 로 휠팬부 좌석의 전반적 만족도인 3.36점에 비해 높은 점 수를 기록했다. 반면에, 좌석 간격에 대한 만족도는 2.93점 으로 매우 낮은 것을 확인할 수 있었다. 즉, 휠팬부 높이가 만족도 저해에 직접적인 영향을 미치지 않았으며 전방 운전 석 격벽과의 간격이 너무 좁아(약 $45 \%$ 가 좁거나 매우 좁다 고 응답함) 휠팬부 좌석의 전반적인 만족도가 낮게 나타난 것으로 확인되었다 $(p<0.01)$.

실제 비디오 관찰에서도 운전석 뒤쪽의 경우 격벽과 스텐 션 폴에 의해 앉고 일어서는 것이 너무 힘들었으며 사람에 따라서 수 차례 반복 시도를 통해 앉는데 성공하거나 혹은 결국 포기하고 다른 자리로 가는 것을 목격할 수 있었다. 하 지만, 전문 부근에 있는 휠팬부 좌석의 경우 공간이 상대적 으로 넓어 큰 불편 없이 앉고 일어 서는 것이 관찰되었다. 


\subsection{Design suggestions}

앞서 살펴본 바와 같이 저상버스 내 불편을 유발하는 대부 분의 인자들은 승객들의 신체 구조적/기능적 특성과 사용 맥락을 설계에 반영하지 않은 것에서 나타난 문제들이다. 이 에 본 연구에서는 위의 3 가지 문제점에 대해 승객의 신체적 특성과 사용 맥락을 고려하여 다음과 같은 설계 제안을 하고 자 한다.

\subsubsection{Providing a flexibility and low physical effort in use of supporting tools}

세 가지 주요 불편함 중 가장 우선적으로 개선이 되어야 할 사항은 '차량 내 입석 시 적절한 신체 지지가 어려움'이다.

현재 저상버스 내 적용중인 신체 지지를 위한 구조물은 핸 드레일, 핸드레일 손잡이, 사이드 핸드레일, 스텐션 폴, 좌석 손잡이 등 다양한 구조물들이 있다.

하지만 이들은 (a) 너무 높거나 너무 멀리 있어 적절한 사 용이 어려운 경우가 많고; 핸드레일, 사이드 핸드레일, (b) 신체 지지를 위해 단독으로 사용되기에는 흔들림이 너무 많 아 적절하지 않으며; 핸드레일 손잡이, (c) 누구나 사용할 수 있지만 개수가 적어 다수가 사용할 수 없거나; 스텐션 폴, (d) 너무 낮고 크기가 작아; 좌석 손잡이, 사용에 불편하다. 이러한 문제들은 유니버설 디자인의 7 가지 원칙 중, Principle 1. Equitable use, Principle 2. Flexibility in use, 및 Principle 6. Low physical effort, Principle 7. Size and space for approach and use 등에 위배된다.

앞서 살펴 보았듯이 차량 내에서 지지 구조물의 이용 패턴 과 불편 요인 조사 결과 몇 가지 패턴들을 확인할 수 있었다. 이들 패턴에 기반하여 승객의 신체 구조적/기능적 특성을 고 려하여 주요 지지 구조물을 선정하고 이들로부터 설계 요인 을 찾아내 저상버스 실내 레이아웃 및 구조물 설계에 적용한 다면 보다 많은 승객들이 쾌적하고 편안한 서비스를 제공받 을 수 있을 것이다. 예를 들면, 승객들이 가장 많이 사용하고, 저상버스 이용에 가장 중요한 구조물인 스텐션 폴의 개수를 늘려주고, 신장의 제약으로 일부만 사용 가능했던 핸드레일 의 높이를 적정한 수준에서 낮춰 주고, 차내 혼잡도가 높을 경우 사용할 수 있도록 사이드 핸드레일의 위치를 낮추고 좀 더 돌출되도록 설계를 한다면 승객들의 신체 구조적/기능 적 특성과 혼잡도 등의 사용 맥락에 따라 적절한 지지 구조 물을 선택하여 사용할 수 있을 것이다.

\subsubsection{Providing an appropriate space on to passing through the aisle}

앞서 살펴본 바와 같이 저상버스 내 구조물 중 통행 편의 성을 저해할 수 있는 구조물로는 핸드레일(혹은 핸드레일
손잡이), 스텐션 폴, 카드 리더기, step 구조 등 다양한 구조 물이 있다.

이들의 문제점을 정리해 보면, (a) 통로 쪽으로 너무 돌출 되어(혹은 치우쳐) 있어 구조물이 직/간접적으로 통행을 방 해하고 있었고(핸드레일, 핸드레일 손잡이, 스텐션 폴 등), (b) 전문 승차 중문 하차 유도로 인해 하차 대기 승객이 중 문으로 몰리지만 적절한 지지 구조물이 부족해 승객이 특정 공간으로 몰려 통행을 방해하였으며(중문부 핸드레일, 스텐 션 폴 등), (c) 카드 리더기가 하나만 설치되어 있는 경우 가 있어 하차 대기 승객이 특정 장소로 집중되게 하고 이로 인해 통행이 매우 불편했으며(카드 리더기), (d) 부적절한 step 구조로 인해 혼잡도에 종속적으로 통행에 영향을 주 고 있는 것으로 나타났다.

이러한 문제들은 유니버설 디자인의 7 가지 원칙 중 Principle 4. Perceptible information, Principle 5. Tolerance for error, Principle 7. Size and space for approach and use 등에 위배된다.

저상버스 내에서 통행에 불편을 주는 요인들은 대부분 실 내 구조물들의 적절하지 않은 layout에 의해 발생하고 있었 으며, 부족한 카드 리더기와 부적절한 step 구조에 의한 것 이었다. 좌석 승객과 입석 승객이 마주하고 있는 지하철에서 등을 대고 핸드레일 손잡이를 잡고 있는 경우에도 약간의 불편함이 있을 뿐 통행을 못하도록 막는 수준은 아니었다. 이 점에서 착안하여 저상버스 내에서 좌석 승객과 입성 승객 이 서로 민망해 하지 않고 편안한 상태에서 핸드레일(혹은 핸드레일 손잡이)을 잡을 수 있는 거리를 간단한 실험을 통 해서 확인해 본 결과 150 200mm 가량 창쪽으로 핸드레 일을 이동할 수 있는 것으로 확인되었다. 이를 양쪽 핸드레 일에 적용을 한다면 현재보다 최소 $300 \mathrm{~mm}$ 에서 최대 400 $\mathrm{mm}$ 까지 상대적으로 넓은 공간을 확보할 수 있는 것이다. 카드 리더기가 1 개인 차량에서는 맞은 편에 1 개를 더 설치 하여 하차 대기 승객의 분산을 유도하며, 중문 부근에 있는 핸드레일의 높이를 적정한 수준으로 낮춰 하차 대기 승객이 신체를 지지할 수 있도록 하여 역시 분산을 유도하고, 가급 적 중문 후방 공간의 step 구조를 없애는 것을 권고하지만, 차량 구조적인 문제로 부득이 step 구조를 적용해야 한다면 승객이 자연스럽게 통로 구역으로 인식하는 지점을 실험을 통해 확인하고 step의 경사를 없애는 방안을 고려해야 할 것이다.

\subsubsection{Providing an appropriate space front wheel pan} seat

전방 휠팬부 시트의 만족도를 저해하는 구조물로는 운전 석 격벽, 스텐션 폴, 전방 휠팬, step 구조 등 다양한 구조물 이 있다. 
이들이 전방 휠팬부 시트의 만족도를 저해하는 요인들을 정리해 보면, (a) 휠팬부 주변의 구조물들의 배치와 형태가 적절하지 않아 앉고 일어서기 힘들게 되어 있으며(운전석 격벽, 스텐션 폴), (b) 높은 휠팬부 시트에 쉽게 오를 수 있도록 도와주는 보조 구조물이 부적절하게 적용되어 있고 (step 구조), (c) 차체 구조적 문제로 휠팬부 시트가 너무 높게 위치(전방 휠팬)하고 있는 것으로 나타났다.

이러한 문제점들은 Principle 1. Equitable use, Principle 3. Simple and intuitive use, Principle 5. Tolerance for error, Principle 6. Low physical effort, Principle 7. Size and space for approach and use 등의 유니버설 디자인 원 칙에 위배된다.

저상버스 내에서 floor 기준 상대적으로 가장 높은 곳에 위치한 전방 휠팬부 좌석이지만 키가 작거나, 힘이 부족한 승객들이나 치마를 입은 승객 등 다수의 승객 집단을 위한 배려가 많이 부족하다. Step 구조의 경우 step이 너무 좁아 유형무실하고, 스텐션 폴이 너무 앞으로 치우쳐 있으면서 아 래 부분이 좌석의 출입구 방향으로 휘어져 있어 출입을 위한 공간을 축소시키고 있으며 운전석 격벽이 지나치게 두꺼워 출입 공간을 좁히는 역할을 하고 있다. 뿐만 아니라 일부 차 량의 경우 휠하우징이 상대적으로 커서 휠팬부 시트를 더 높게, 출입구를 더 좁게 만들고 있었다.

운전석 격벽은 운전자에게 안락하고 안전한 작업 공간을 제공하기 위한 최소한의 공간을 마련하기 위한 구조물로 매 우 중요한 역할을 수행하고 있어 운전자의 안락한 운전영역 과 안전을 제공할 수 있는 범위와 격벽의 적절한 두께를 찾 아 적용해야 할 것이다. 그 밖의 구조물들에 대해서는 승객 의 사용 맥락에 근거한 설계적 개선이 필요해 보인다. 예를 들면 아래쪽이 휘어진 구조로 된 스텐션 폴을 직선형태나 부득이 한 경우 밴딩각도를 키워 최대한의 출입 공간을 확보 해 주는 것이 필요하며 step을 좀 더 확장하여 보다 편하게 발을 디딜 수 있도록 해야 할 것이다.

\section{Discussion}

흔히들 유니버설 디자인이라 하면 노약자나 신체적/감각적 /정신적 장애를 가지고 있는 사람들을 위한 디자인이라고 잘 못 생각하는 경우가 많다. 하지만, 본 연구의 사례에서 살펴 본 바와 같이 유니버설 디자인은 불특정 다수의 다양한 사용 자들이 제품이나 시스템을 이용하는데 보다 편리하도록 하 는 것이다.

사용 편리성을 높여가기 위한 디자인 고려사항으로써 신 체적 장애가 있거나 세월에 의해 신체적/감각적 노화가 진행
된 고령자 혹은 일반인들과 비교해 신체적 특성이 다른 사 람들의 입장에서 제품(혹은 시스템)을 설계 개발함으로써 지금까지 전혀 느끼지 못 했던 어떤 것을 발견할 수 있는 것 이다.

고령자 그룹이 교통약자의이동편의증진법에서 정한 교통 약자 중 저상버스를 이용함에 있어 가장 위험도가 높은 그 룹일 것이다. 장애인, 임산부, 영유아를 동반한 자들은 보다 안전한 좌석을 양보 받는 경우가 많고, 어린이의 경우 보호 자를 동반하는 경우가 보통이다. 하지만, 고령자의 경우 자 리를 양보 받지 못 하는 상황을 이번 비디오 관찰을 통해서 가끔 확인할 수 있었다. 이들 고령자는 젊은 시절에 비해 키 가 줄어들어 높은 곳에 위치한 핸드레일 등을 잡기 어렵고, 운동기능이 저하와 근골격의 쇠퇴로 핸드레일 손잡이만으로 급정거 등의 비상상황에 적절한 대처가 쉽지 않다. 또한 좌 석에 앉아 있을 때에도 앞 좌석의 손잡이를 잡고 있는 것을 자주 관찰할 수 있었다. 이러한 현상은 좌석에 앉아 있긴 하지만, 상대적으로 신장이 작은 고령자에게 적절하지 않은 규격의 시트와 흔들림이 많은 버스의 특성이 복합적으로 반 영된 것으로 판단된다.

저상버스의 실내 구조물 설계에 있어 유니버설 디자인 측 면에서 반드시 고려해야 할 대상군 중 하나가 일반인 가운 데 상대적으로 키가 작은 승객들이다. 저상버스의 어느 영 역에서나 쉽고 안전하게 신체를 지지할 수 있는 구조물 중 하나가 차량의 천장에 장착되어 있는 핸드레일이다. 하지만, 이는 너무 높이 위치하여 키가 큰 승객들만이 사용할 수 있 었다. 30 40대의 경우 평균키의 남성들도 사용은 가능했지 만 팔을 거의 일직선에 가깝게 뻗어야만 사용할 수 있어 적 절한 신체 지지를 위해 보다 큰 힘을 필요로 했다. 이로 인 해 일반인 중 키가 작은 승객들은 대부분 스텐션 폴을 감싸 안거나 핸드레일 손잡이와 주변 구조물을 중복 지지함으로 써 신체를 안전하게 지지하려 하였다. 뿐만 아니라 일부 좌 석의 경우 이들이 앉기에 너무 높아 고령자와 비슷한 불편 을 감수해야만 했다.

\section{Conclusion}

본 연구에서는 저상버스 이용에 불편함을 주는 요인을 찾 아내고 이들에 대해 유니버설 디자인 측면에서 교통약자와 일반인 모두에게 동일한 편의와 만족을 제공할 수 있는 방안 에 대해 논의하였다.

이를 위해 설문조사와 심층인터뷰를 통해 저상버스 내 구 조물 이용의 편의와 만족도 및 불편 요인을 정량적으로 평 가하였으며 동시에 비디오 관찰을 통해 승객의 행동을 정성 
적으로 관찰함으로써 설문과 인터뷰 결과에 대한 확인/검증 및 설문과 인터뷰를 통해 밝혀내지 못한 무의식적인 행동에 기반한 사건들을 찾아내고자 하였다. 이를 통해 교통약자와 일반인 모두를 포함한 승객들이 저상버스를 이용함에 있어 불편한 사항들을 도출하였고 승객의 행동 패턴과 실내 구조 물의 사용 맥락을 고려하여 유니버설 디자인 측면에서 새로 운 디자인 방안을 제안하였다.

주로 지지 구조물의 이용에 대해 편의성이 떨어지고 이용 만족도가 낮은 것으로 나타났으며 교통약자와 일반인, 성별, 혼잡도와 외부환경적 요인 등의 사용 맥락에 따라 구조물 이용에 차이가 있었다. 또한, 이들 지지 구조물들은 부적절한 공간배치로 통행에 불편을 주는 요인으로 작용하고 있었다.

경사진 step 구조는 차량 내 체류와 통행을 저해하는 요 인 것으로 확인이 되었으며 중문 부근의 여러 구조물들의 적절하지 못하고 비효율적인 배치는 하차 대기 승객을 특정 한 위치로 집중시키게 하는 효과가 있었으며 이로 인해 중문 부근이 혼잡해져 차량 내 통행에 큰 방해 요인으로 작용하 였다.

그 밖에 전방 휠팬부 좌석의 경우 차량 구조적 문제로 일 부 불편함을 감수하고 사용을 하고 있었지만, 역시 주변 구 조물들의 공간배치 문제와 사용 맥락을 고려하지 않은 형상 등으로 인해 앉고 일어서기에 매우 불편한 것으로 확인되 었다.

이들 문제점들은 대부분 유니버설 디자인 원칙과 승객의 행동 패턴 및 사용 맥락의 고려가 부족하여 나타난 결과인 것으로 판단된다.

승객의 차내 행동 패턴과 사용 맥락을 고려하여 신체 지지 구조물별 차별화를 실시하고 그에 적합한 제원을 설정하여 이를 설계에 반영하고 적절한 공간배치를 한다면 교통약자 와 일반인 모두 저상버스를 이용함에 있어 만족할 만한 수 준의 편의성과 안락감을 제공할 수 있을 것으로 기대된다.

본 연구를 수행하면서 상당 기간 동안 저상버스에 탑승하 고 이동하면서 설문조사와 인터뷰를 실시하고 비디오 관찰 을 실시했지만 휠체어를 이용하는 승객이 실제로 탑승한 사 례를 볼 수 없었다. 휠체어를 이용하는 승객이 탑승했을 경 우 이들의 행동 패턴과 사용 맥락은 일반인과는 확연하게 차이가 있으리라 생각된다. 추후에는 일반인들과 다른 행동 패턴과 사용 맥락을 보일 수 있는 휠체어 이용 승객과 신체 적 장애를 가진 승객들을 본 연구에서 보다 비중 있게 고려 한다면 좀 더 다양한 시각을 반영한 연구를 할 수 있을 것 이다.

\section{Acknowledgements}

This work was supported by Hyundai-Motor Corporation.

\section{References}

Agneta Fange and Susanne Iwarsson, Accessibility and usability in housing: construct validity and imlications for research and practice, Disability and Rehabilitation, 25(23), 1316-1325, 2003.

Beecher, V. and Paquet, V., Survey instrument for the universal design of consumer products, Applied Ergonomics, 36, 363-372, 2005.

Hwan, Hwang Bo, et al. A study on low-floor bus passenger behavior patterns using video ethnography, proceedings of the 2010 ESK Fall Conference and Workshop, 2010.

Jonathan C. Levine and Gwo-Wei Torng, Dwell-time Effects of Low-floor bus design, Journal of Transportation Engineering, 120(6), 914-929, 1994.

Kang, Kyung Woo, et al. Reconsideration The Relationship Between The Rapid Aging of The Societies and The Older Drivers' Traffic Accidents, The KSCE Journal of Civil Engineering, 27(1), 19-26, 2007.

$\mathrm{Kim}$, Ji Yeon, et al. A study on the low-floor bus layout for universal design, proceedings of the 2011 ESK spring Conference and Workshop, 2011.

Kim, Mi Yeon, et al. Development Process of a Universal Design Evaluation Index with a Case Study for Mobile Phone Evaluation, Journal of the Ergonomics Society of Korea, 25(4), 51-62, 2006.

Kim, Wonho, et al. A Study on Travel Behavior of the Mobility Handicapped and Custom-made Transit Information System, Seoul Metropolitan Research, 9(2), 105-119, 2008.

Ma, Kang-Rae and Yoon, Young-Ho, A Study on the Changes in Travel Mode Choice of Elderly, Seoul Metropolitan Research, 10(4), 159 $-171,2009$.

Maguire, M., Context of Use within Usability Activities, International Journal of Human-Computer Studies, 55, 453-483, 2001.

Ministry of Construction and Transportation, Barrier-Free Transporation, 2007.

NARK, Promotion raw of mobility for transportation handicapped, a law No. 7382, 2005. 1.27 enactment.

Rutenberg, Uwe, and Hunter-Zaworski, Kate, Access to over the road buses for passengers with disabilities, Conference COMOTRED 2007, 2007.

Sharp, H., et al. Interaction Design - Beyond Human-Computer Interaction, $2^{\text {nd }}$ ed, John Wiley, Chichester, 2007.

Seo, Sang Eun, et al. Analysis of the Elderly Travel Characteristics and Travel Behavior with Daily Activity Schedules (the Case fo Seoul, Korea), The Journal of Korean Society of Transportation, 24(5), 89 $-108,2006$.

Seoul City, Public Transportation Plan in Seoul, Seoul City, 2007.

Seoul City, Traffic Safety Action Plan, 2010. 
Size Korea, Report of the $5^{\text {th }}$ Human Dimension Research Project of Korean, 2004.

Song, Bok Hee, et al. The Universal Design of Microwave Oven considering Old Persons, Journal of the Ergonomics Society of Korea, 19(1), 37 $-48,2000$.

Story, M. F., Maximizing Usability: The Principles of Universal Design, Assistive Technology: The office Journal of RESNA, 10(1), 4-12, 1998.

Universal Design Research Center, Knowing about Universal Design, 2010, http://udrc.or.kr.

Universal Design Research Center, The Needs of Universal Design for Aging society, 2010, http://udrc.or.kr

Valerie Beecher and Victory Paquet, Survey instrument for the universal desing of consumer products, Applied Ergonomics, 36, 363-372, 2005.

Wikipedia, Universal Design, http://ko.wikipedia.org/wiki/\%EC\%9C\%A0\% EB $\% 8 \mathrm{~B} \% 88 \% \mathrm{~EB} \% \mathrm{~B} 2 \% 84 \% \mathrm{EC} \% 84 \% \mathrm{~A} 4 \% \mathrm{~EB} \% 94 \% 94 \% \mathrm{EC} \% 9$ E\%90\%EC\%9D\%B8, (retrieved Jul, 10, 2011).

Zerald Zaltman, How customers think: essential insights into the mind of the market, Harvard Business Press, 2003.

\section{Author listings}

Sun Woong Kim: namiso@yonsei.ac.kr

Highest degree: M.S., Department of Industrial Engineering, the University of Jeonju

Position title: Ph.D Candidate, Department of Industrial Engineering, the University of Yonsei

Areas of interest: Human Factors in Automobile, HCI, Vehicle

Comfort/Discomfort

Ji Yeon Kim: jykim29@yonsei.ac.kr kr

Highest degree: B.S, Department of Information \& Industrial

Engineering, the University of Hongik

Position title: M.S Candidate, Department of Information \& Industrial

Engineering, the University of Yonsei

Areas of interest: Human Factors in Automobile, HCI, Interior Packaging
Hwan-Hwangbo: hwan976@yonsei.ac.kr

Highest degree: B.S, Department of Information \& Industrial Engineering, the University of Yonsei

Position title: M.S Candidate, Department of Information \& Industrial Engineering, the University of Yonsei

Areas of interest: Human Factors in Automobile, HCI

Bong-Ha Hwang: yibeizi@hyundai.com

Highest degree: M.S, Department of Mechanical Engineering, the University of Yonsei

Position title: Research Engineer, Commercial Vehicle Project Team, Hyundai Motor Company

Areas of interest: Universal design, Human Factors in Automobile, Interior Packaging

Young Joo Moon: myjoo@hyundai.com

Highest degree: B.S, Department of Mechanical Engineering, the Busan national university

Position title: Part Manager, Commercial Vehicle Project Team, Hyundai Motor Company

Areas of interest: Universal design, Human Factors in Automobile, Interior Packaging

Yong Gu Ji: yongguji@yonsei.ac.kr

Highest degree: Ph.D, Department of Industrial Engineering, the University of Purdue

Position title: Professor, Department of Industrial Engineering, the University of Yonsei

Areas of interest: Human Factors in Automobile, HCI

Date Received : 2011-07-18

Date Revised : 2011-07-28

Date Accepted : 2011-08-02 